\title{
Are we citizens adrift or citizens assured?
}

\section{Angela Mazza}

\author{
Department of French Language and Cultural Studies, UCC
}

What does citizenship mean to you? What role does your nationality play in your identity? I am a person of dual nationality; I am born in America and my father was Irish. I grew up never feeling truly American, as my mother was Italian and my dad; , having lived most of his adult life in California, remained pure Irish, from the friends he played golf with to an accent none of my American friends could understand. I remained 'on the fence' regarding my American citizenship. Although we lived in southern California, all our family friends came from Ireland and my house was always filled with people visiting from Europe.

After America went to war, I moved my family to Ireland in search of a different way of life far from the hectic insanity of Los Angeles and I found myself in Cork in 2003, in a completely different world. In some ways, I felt I was home; I finally understood the part of me that was Irish and yet, there are times when I still feel an outsider in the same way I did in America, not really feeling American and not quite Irish.

In my choosing of the subject of my dissertation, Alexis de Tocqueville, Democracy America: The Influence of French Citizenship on the Theoretical Vision of Tyranny of the Majority, I can explore the manner in which our citizenship influences our visions of other countries and cultures. By gaining a better understanding of citizenship, one can recognize the bias that exists as a characteristic of nationality. In seeking to safe-guard the power of the individual; citizen participation requires a perspective aware of any prejudice created by culture. There must be recognition of the influence of cultural practices and an understanding of how historical references impact on a citizen's view of citizenship, in order to obtain the power to create change and move forward.

\section{Connection, participation, and patriotism}

After one year of research, I am hardly an expert on the complexity of citizenship. However, I do believe that, in order to be a true citizen, three components of citizenship must take place physically and mentally. The citizen must feel a connection, participation, and a sense of patriotism to the country of their birth or the country of their choice.

Let's examine those three ideas further. The idea of obtaining a connection to something bigger than ourselves, whether it is a political concept, a religious viewpoint or a society as a whole is an interesting and enlightening prospect for any human being. Everyone on 
earth is seeking answers and desires a place by which they can offer their own individualistic characteristics to an enormous melting pot of millions of other human beings. It is in our nature to crave acceptance and seek out similarities of ourselves in others. Citizenship creates a partnership with a country and the inhabitants of that country. In other words, we become a member of that club, an organization that can offer a safe place in which to show our true identity.

In my research, I am discovering that, if one observes human behavior, they can discover a link between the citizenship and opinion. Our thoughts and reactions to circumstances stem from the historical events of our nation's past. For Alexis de Tocqueville, the death and destruction of his ancestors during the French Revolution would have a profound effect on his own vision of France and subsequently, America. In Ireland today, one may relate to their ancestors' need to immigrate and establish a life away from their native homeland. However, the citizenship connection will not cease to exist upon the departure of the citizen. The boundaries of citizenship are uniquely limited to the participation of the individual. Therefore, as ex-patriots are permitted to vote in elections, Irish citizens retain their right to create change.

Participation is the best way a citizen can influence decisions both politically and socially. Participation requires a motivation to become involved, and in my research, I have discovered that in all nationalities studied so far, the common link appears to be that citizens often do not participate for two reasons. One is a sense of powerlessness and a belief that their vote will not matter and their voice will go unheard and the other reason is basic cynicism about how politics will play out in their country, and that there is no real solutions to political issues. They prefer to not include their votes or ideas as they have already chosen to give up on their citizenship and believe that their opinions can no longer make a difference. In many ways the media and sometimes politicians themselves, help that ideology to thrive. Yet, without participation, citizenship is weakened and there is an exclusion of voices that have something to say. We all have something to contribute to our country as each of us has a unique vision of life. Therefore, in order to share our knowledge, participation in the making of the laws and the choosing of our politicians must occur in order for our ideas to matter and for change to be created.

Patriotism has been described by great literary minds over the centuries as a result of a successful relationship between the State and the people. In other words, I feel good about my country; therefore, I am patriotic. However, what about when things get tough, when the economic climate is so bleak that people feel they have to flee to other countries to earn their crust of bread? My dad immigrated to America and I returned to Ireland. I am here now because I believe every country has so much to offer and we need to seek out opportunities to make things work with a positive energy. I know it is appealing to immigrate to other countries when times are tough or when a country chooses to go to war and you are pro-peace. I know it is easy to listen to the media tell us the sky is falling 
and we are all doomed. It is normal to want to walk away and create a new beginning. Therefore, as patriotic citizens, it is necessary to take action when times are difficult. It is important to establish a belief in your country again. That does not mean one should not experience other countries and cultures. A citizen can retain the ability to contribute to changing their country and changing the rules. That is why you can vote when you live abroad, you still have your say. The question is; are you a citizen on a raft, waiting for rescue, despondent and discouraged, or are you the citizen assured that feels empowered and motivated to create a better world?

\section{Discovering our citizenship identity}

The complexity of citizenship means it can be broken down to many different components. However, it is important to recognize the significance of connection, participation, and patriotism as three ways we can demonstrate our citizenship identity. Therefore, it is important to discover the connection between ourselves and the nation of our birthright or our adopted homeland in order to better understand ourselves. Perhaps it is necessary to participate as a citizen to create change and for our country to progress and if so, we need to find our patriotism and allow that bond to bring a positive energy into our lives. In order to better understand our identity, we need to ask ourselves what citizenship means to our individuality, and how our citizenship influences the way we see our world. When we reflect on our nationality, can we remove self-interest in order to do what is best for our country as a whole? Maybe not, yet we can try to balance the scale between what is best for ourselves and what is best for the state by bringing together a connection to society, a participation to create change and progress, and most importantly, loving our country where we are born and/or the country we have adopted. In my research thus far, I have learned that the path we take in life is often influenced by our ancestors. The vision we see of the world is dependent on our childhood memories and the historical events of our nation. I fear for the perspective of future generations growing up in a world of such negativity and greed. As citizens, our only recourse is to demand changes be made both politically and socially in a worldwide desire for equality and freedom. Creating this kind of partnership requires the ability to look beyond self-interest and seek out the actions one can take to improve their country for future generations. The devotion to our future fellow citizens defines our humanity.

Angela Mazza is a student for the Department of French Language and Cultural Studies and supervised by Dr. Paul Hegarty and Dr. Patrick Crowley. The author would like to acknowledge the advisors and the entire French Department for their support, wisdom, and kindness. 